\title{
Evaluating the impacts of some environmentally relevant factors on the availability of bisphenol A with negligible-depletion SPME
}

\author{
Xia-lin $\mathrm{Hu}^{\text {a }}$, Jin-feng Peng a , Jing-fu Liu ${ }^{\text {a,* }}$, Gui-bin Jiang a , Jan Åke Jönsson ${ }^{\text {b }}$ \\ a State Key Laboratory of Environmental Chemistry and Ecotoxicology, Research Center for Eco-Environmental Sciences, \\ Chinese Academy of Sciences, P.O. Box 2871, Beijing 100085, China \\ ${ }^{\mathrm{b}}$ Department of Analytical Chemistry, Lund University, P.O. Box 124, S-221 00 Lund, Sweden
}

Received 24 March 2006; received in revised form 7 July 2006; accepted 10 July 2006

Available online 22 August 2006

\begin{abstract}
The effect of some environmentally relevant factors including salinity, $\mathrm{pH}$, and humic acids on the availability of bisphenol A (BPA) was evaluated by using the negligible-depletion solid-phase microextraction (nd-SPME) biomimetic method. With the variation of salinity $(0-500 \mathrm{mM} \mathrm{NaCl})$ and $\mathrm{pH}(5.0-8.5)$ of aqueous solutions, the partition coefficients of BPA between the nd-SPME fiber and the aqueous solution varied in the range of $\log D=3.55-3.86$, which indicates that the salinity and pH can influence the availability of BPA. By using Acros humic acid as model dissolved organic matter (DOM), it was also demonstrated that the environmental factors such as salinity and $\mathrm{pH}$ could affect the partitioning of BPA between DOM and aqueous solutions. The determined partition coefficients of BPA between dissolved organic carbon (DOC) and aqueous solutions were in the range of $\log D_{\mathrm{DOC}}=4.03-5.60$ for Acros humic acid solutions with $1-50 \mathrm{mg}^{-1}$ DOC. The influence of salinity and $\mathrm{pH}$ on $\log D_{\mathrm{DOC}}$ was more significant at low concentration $\left(0-5 \mathrm{mg} \mathrm{l}^{-1}\right)$ of DOC.
\end{abstract}

(C) 2006 Elsevier Ltd. All rights reserved.

Keywords: Negligible-depletion solid-phase microextraction; Partitioning; Availability; Bisphenol A; Dissolved organic matter; Humic acids

\section{Introduction}

Various environmentally relevant factors such as dissolved organic matter (DOM), salinity and $\mathrm{pH}$ might influence the availability of a contaminant in aquatic environments. For example, binding and adsorption by particles and DOM can alter the bioavailability of a contaminant. The freely dissolved concentration $\left(C_{\text {free }}\right)$ is believed to be the driving force for the transportation, distribution, and bioaccumulation of a contaminant (Mackay and Paterson, 1991), and thus a key parameter controlling its bioavailability and the toxic effect (Suffet et al., 1994). Therefore, study on the effects of environmental factors on the $C_{\text {free }}$ or the partitioning between DOM and aqueous

\footnotetext{
* Corresponding author. Tel.: +86 10 62849334; fax: +861062849179. E-mail address: jfliu@rcees.ac.cn (J.-F. Liu).
}

solutions can elucidate their influence on the bioavailability of a contaminant. The partitioning between DOM and an aqueous solution of a contaminant is usually normalized to dissolved organic carbon (DOC) and expressed as $D_{\mathrm{DOC}}$.

Many studies about the effect of environmentally relevant factors on the bioavailability of hydrophobic compounds have been reported, and the effect of DOM was the mostly concerned (Carter and Suffet, 1982; Kukkonen and Oikari, 1987; Day, 1991; Chin et al., 1997). Haitzer et al. (1998) reviewed the effects of DOM on the bioconcentration of organic chemicals in aquatic organisms. It was concluded that the presence of DOM in most cases caused decrease of bioconcentration while in a few cases lead to enhance of bioconcentration, and the effect of DOM depends on its sources. The environmental $\mathrm{pH}$ can affect the ionization of DOM (Jota and Hassett, 1991) and thus influence the binding of neutral hydrophobic compounds to DOM (Paolis and Kukkonen, 1997). Depending on the 
ions used to control the ionic strength and the properties of DOM, the ionic strength or salinity can increase (Gauthier et al., 1986; Jota and Hassett, 1991; Brunk et al., 1997) or decrease (Schlautman and Morgan, 1993; Jones and Tiller, 1999) the association of DOM with polychlorinated biphenyls (PCBs) or polycyclic aromatic hydrocarbons (PAHs). By using negligible-depletion solid-phase microextraction (nd-SPME), a biomimetic tool, the combined effects of humic acids and salinity on the availability of 4,4'-dichlorodiphenyltrichloroethane (DDT) and chlorpyrifos pesticides were investigated, and it was reported that the binding of DDT and chlorpyrifos by humic acids was greatly reduced with the presence of salt (Mezin and Hale, 2004).

For ionizable compounds, however, studies on their bioavailability and their association with DOM were limited. Schwarzenbach and co-workers investigated the partition in liposome-water system of a series of substituted phenols and anilines with $\mathrm{pH}$ dependent results (Escher and Schwarzenbach, 1996; Escher et al., 2002) and Arnold et al. also found that the association of triorganotin compounds with dissolved humic acids was strongly $\mathrm{pH}$ dependent (Arnold et al., 1998). A few studies on the association of chlorophenols with various DOM were reported. Depending on the source of DOM, the sorption coefficients $\left(\log K_{\mathrm{oc}}\right)$ of pentachlorophenol ranged from 0 to 3.9 at $\mathrm{pH} 5.0$, and the $\log K_{\mathrm{oc}}$ value decreased radically with the increase of $\mathrm{pH}$ and reached 0 for almost all kinds of DOM at pH 8.0 (Paolis and Kukkonen, 1997). Aldrich humic acid and chlorophenols have strong and $\mathrm{pH}$ dependent association (Ohlenbusch et al., 2000; Liu et al., 2005). The measured $\log K_{\mathrm{oc}}$ value for pentachlorophenol was 3.0 at $\mathrm{pH} 7.3$, and the $\log K_{\mathrm{oc}}$ values for 2,5-dicholophenol were 2.76 at $\mathrm{pH} 6.5,2.60$ at $\mathrm{pH} 7.3$, and 1.66 at $\mathrm{pH} 8.3$, respectively (Ohlenbusch et al., 2000). For ionogenic compounds with $K_{\mathrm{ow}}<2$, the association of atrazine with DOM was very low (Akkanen and Kukkonen, 2001) while 4-quinolone antimicrobials (Flumequine, oxolinicacid, and sarafloxacin) showed very large distribution coefficients $\left(\log D_{\mathrm{DOC}}=3.4-5.2\right)$ with Aldrich humic acid (Lutzhoft et al., 2000).

Bisphenol A (BPA), a relatively polar compound (log$\left.K_{\mathrm{ow}}=3.40, \mathrm{p} K_{\mathrm{a}}=9.6-10.2\right)$ with known endocrine potential, is one of the most produced chemical intermediate used to make polycarbonate plastic, expoxy resins, flame retardants, and other special products (Staples et al., 1998). However, studies on the binding of BPA to DOM and the effect of DOM on the bioavailability of BPA are scarce. Although the distribution coefficient between DOM and water of BPA has been measured $\left(K_{\mathrm{DOM}}=\right.$ $8601 \mathrm{~kg}^{-1}$ ) (Hollrigl-Rosta et al., 2003), the effect of other environmental relevant factors such as $\mathrm{pH}$ and salinity on the bioavailability of BPA is not clear. A few studies on the determination of BPA by SPME were reported (Salafranca et al., 1999; Braun et al., 2003; Cai et al., 2004; Basheer et al., 2005; Chang et al., 2005), but there is no report on the effect of environmental relevant conditions on the availability studied with the nd-SPME technique.
In this present study, the effect of humic acids $\mathrm{pH}$ and salinity on the availability of BPA was evaluated by using the nd-SPME biomimetic method. The direct effects of $\mathrm{pH}$ and salinity on the availability were studied by measuring their influence on the partitioning of BPA to the fiber $(D)$, while the combined effects of these factors with humic acids were investigated based on their influence on the partitioning of BPA to humic acids $\left(D_{\mathrm{DOC}}\right)$.

\section{Experimental section}

\subsection{Reagents and materials}

All reagents were of analytical-reagent grade and deionized water was used throughout the experiments. BPA (Acros Organics, NJ, USA) standard stock solution $\left(1000 \mu \mathrm{g} \mathrm{ml}^{-1}\right)$ was prepared in methanol, and working solutions were prepared daily by appropriate dilution of the stock solution with water. Humic acid sodium salt made from terrestrial origin (lignite, technical, $50-60 \%$ as humic acid; Acros Organics, Morris Plains, NJ) was used as obtained. The DOC of this humic acid sodium salt (measured in a solution prepared by dissolving $20 \mathrm{mg}$ in $200 \mathrm{ml}$ of water and filtrated through $0.45 \mu \mathrm{m}$ membrane, with a Phoenix 8000 UV-persulfate TOC Analyzer, Tekmar Dohrmann, USA) was $45.0 \%$.

LC-grade methanol and acetonitrile were purchased from Scharlau Chemie SA, Barcelona, Spain. Other chemicals such as sodium dihydrogen phosphate, sodium hydroxide, sodium chloride, and hydrochloric acid were obtained from Beijing Chemicals Corporation (Beijing, China).

\subsection{Instrument}

The HPLC system was equipped with an Agilent 1100 Series isocratic pump (IsoPump) and an Agilent 1100 Series fluorescence detector (FLD). The fluorescence detector was set at $220 \mathrm{~nm}$ excitation and $315 \mathrm{~nm}$ emission wavelength, respectively. A personal computer equipped with an Agilent ChemStation program for LC system was used to process chromatographic data. A manual SPME fiber holder (type 57331) and a SPME-HPLC interface from Supelco Inc (Bellefonte, PA) were used to conduct the extraction and introduce the analyte extracted on the fiber into the HPLC system. The SPME-HPLC interface consisted of a six-port Rheodyne valve and a $60-\mu$ l desorption chamber.

A pH 211 microprocessor pH meter (Hanna Instruments) was used to adjust the sample $\mathrm{pH}$.

\subsection{HPLC separation}

The separation of BPA was performed on an Agilent Zorbax Eclipse $\mathrm{XDB}-\mathrm{C}_{8}$ column $(150 \times 4.6 \mathrm{~mm}$, particle size $5 \mu \mathrm{m}$, pore size $8 \mathrm{~nm}$, polymeric, double endcapped) by using a mixture $(75: 25, \mathrm{v} / \mathrm{v})$ of acetonitrile and phosphate

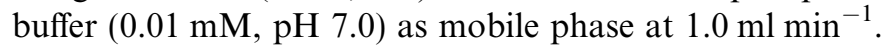


For quantification of the amount of BPA extracted onto SPME fiber, a calibration curve was prepared by injecting $20-\mu 1$ aliquots of BPA in phosphate buffer solution (0.01 mM, pH 7.0).

\section{4. nd-SPME procedure}

A 50- $\mu \mathrm{m}$ CW/TPR fiber from Supelco Inc. (Bellefonte, PA) was used for SPME of BPA. Before the first use of a new fiber, it was conditioned with the mobile phase until a stable baseline was obtained. Prior to the first extraction each day, the fibers was conditioned by inserting into the interface for washing a few minutes by the mobile phase, then the fiber was kept in air for about 3 min to eliminate the organic solvent from the mobile phase. This latter procedure of exposure to air was conducted before every extraction to avoid the residual organic solvent degrading the next extraction efficiency. In this way, freshly conditioned fibers were immediately available for the next extraction and no carryovers were observed.

For extraction, $100 \mathrm{ml}$ of sample solution placed in a glass flask sealed with a hole cap and Teflon septa was stirred with a magnetic stirrer at its maximum agitation speed, and then the septum was pierced by the SPME needle and the fiber was completely immersed into the stirred solution for a predetermined time at room temperature. After extraction, the fiber was removed and inserted into the desorption chamber of the SPME-HPLC interface for dynamic desorption, i.e., the analytes were desorbed by the moving stream of mobile phase at flow rate of $0.2 \mathrm{ml} \mathrm{min}^{-1}$ during the first $2 \mathrm{~min}$, then the flow rate was increased to $1 \mathrm{ml} \mathrm{min}^{-1}$.

Equilibration time and sample depletion. The fiber was exposed to individual flasks containing $100 \mathrm{ml}$ of $50 \mu \mathrm{g}^{-1}$ BPA sample solution for various time periods to obtain the uptake profiles. BPA solutions prepared in $200 \mathrm{mM}$ phosphate buffer ( $\mathrm{pH} 7.0), 5 \mathrm{mM}$ phosphate buffer ( $\mathrm{pH} 7.0$ ), or a mixture of $5 \mathrm{mM}$ phosphate and $500 \mathrm{mM} \mathrm{NaCl}$ $(\sim 3.0 \% \mathrm{NaCl}, \mathrm{pH} 7.0)$ were adopted to study the effect of salinity, while BPA in $30 \mathrm{mM}$ phosphate buffer $(\mathrm{pH}$ 5.0 or $\mathrm{pH} 8.5$ ) to investigate the effect of variation of $\mathrm{pH}$.

Influence of salinity and $\mathrm{pH}$. The fiber was exposed to individual flasks containing $100 \mathrm{ml}$ of $50 \mu \mathrm{g} \mathrm{l}^{-1} \mathrm{BPA}$ sample solutions with environmentally relevant salinity $(0$ $500 \mathrm{mM} \mathrm{NaCl})$, and $\mathrm{pH}(5.7-8.5)$ for the above determined equilibration time $(4 \mathrm{~h})$, respectively.

Combined effects of humic acids with salinity and $p H$. The fiber was exposed in individual flasks containing $100 \mathrm{ml}$ of $50 \mu \mathrm{g}^{-1}$ BPA and various concentration of humic acid (0$50 \mathrm{mg}^{-1}$ DOC) sample solutions prepared in $125 \mathrm{mM}$ phosphate buffer ( $\mathrm{pH} 7.0), 5 \mathrm{mM}$ phosphate buffer $(\mathrm{pH}$ 7.0 ), and $5 \mathrm{mM}$ phosphate buffer ( $\mathrm{pH} 6.0)$, respectively, for the above determined equilibration time $(4 \mathrm{~h})$.

\subsection{Data processing}

All experiments were duplicated and the mean values were reported. Some of the experimental values (Fig. 1) were
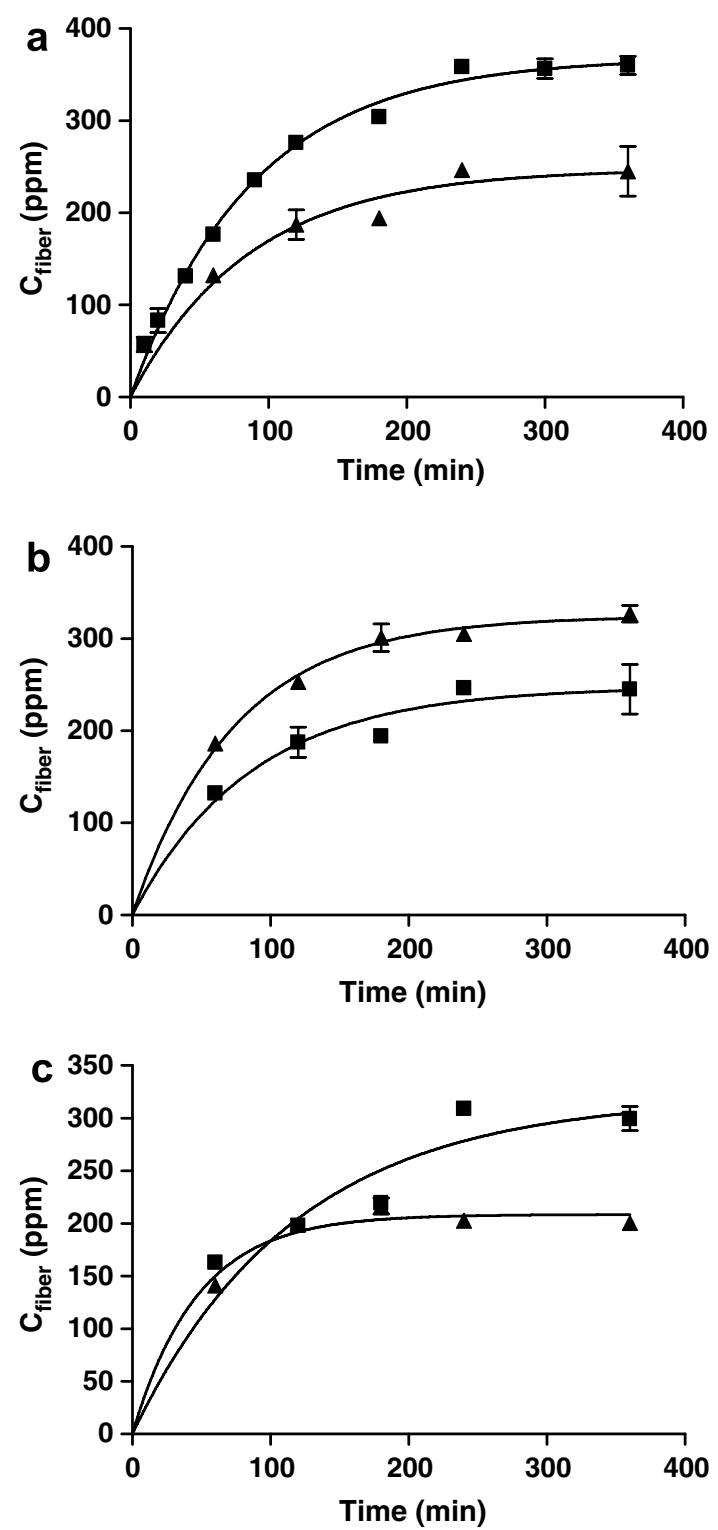

Fig. 1. The uptake profiles of BPA $\left(50 \mu \mathrm{g}^{-1}\right)$ to the SPME fiber under environmentally relevant salinity and $\mathrm{pH}$. The vertical lines represent the standard deviations. (a) Effect of phosphate concentration ( $\mathrm{pH} \mathrm{7.0):} \mathbf{\square}$, $200 \mathrm{mM}$; $\boldsymbol{\Delta}, 5 \mathrm{mM}$. (b) Effect of $\mathrm{NaCl}$ concentration $(5 \mathrm{mM}$ phosphate buffer, pH 7.0): $\mathbf{\square}, 0 \mathrm{mM} \mathrm{NaCl} ; \boldsymbol{\Delta}, 500 \mathrm{mM} \mathrm{NaCl}$. (c) Effect of $\mathrm{pH}$ (30 mM phosphate buffer): $\boldsymbol{\square}, \mathrm{pH} 5.0 ; \boldsymbol{\Delta}, \mathrm{pH} 8.5$.

also fitted to a first-order one-compartment uptake model modified from reference (Mayer et al., 2003) by using Graphpad Prism (ver. 4.1, GraphPad Software, San Diego, CA):

$C_{\text {fiber }}(t)=C_{\text {sample }} \cdot D \cdot\left(1-\mathrm{e}^{-k \cdot t}\right)=C_{0} \cdot D \cdot\left(1-\mathrm{e}^{-k \cdot t}\right)$,

where $C_{\text {fiber }}(t)$ is the analyte concentration on the fiber at time $t, C_{\text {sample }}$ is the analyte concentration of sample which can be regarded as a constant that equals to its initial concentration $\left(C_{0}\right)$ in nd-SPME, $k$ is the rate constant and $D$ is the distribution coefficient between the fiber and the aqueous solution. The $C_{\text {fiber }}$ was calculated as in Eq. (2):

$C_{\text {fiber }}=\frac{20 \cdot C}{V_{\text {fiber }}}=\frac{20 \cdot C}{0.330}=60.6 C$, 
where $C$ is the concentration that was calculated from the HPLC peak area obtained from the desorption of the extracted BPA on the fiber and a calibration curve prepared by injecting $20-\mu l$ aliquots of BPA in phosphate buffer solution $(0.01 \mathrm{mM}, \mathrm{pH} 7.0)$, and $V_{\text {fiber }}$ is the fiber coating volume $\left(V_{\text {fiber }}=0.330 \mu\right.$, calculated as a cylindrical layer of polymer coating around the silica rod with a diameter of $160 \mu \mathrm{m}$ and a fiber length of $1 \mathrm{~cm}$ ).

At equilibrium of nd-SPME, the $D$ value can also be calculated from the ratio of $C_{\text {fiber }}$ to $C_{\text {sample, }}$, and $C_{\text {sample }}$ can be regarded as a constant that equals to its initial concentration $\left(C_{0}\right)$ :

$D=\frac{C_{\text {fiber }}}{C_{\text {sample }}}=\frac{C_{\text {fiber }}}{C_{0}}$.

The $k$ value obtained from Eq. (1) can also be adopted to estimate equilibrium sampling times (e.g. $t_{90 \%}=\ln (0.10) /$ $\left.(-k), t_{95 \%}=\ln (0.05) /(-k)\right)$. The $D$ value obtained from Eq. (1) was also used to calculate the sample depletion based on the sample volume $\left(V_{\text {sample }}\right)$ and fiber volume $\left(V_{\text {fiber }}=0.330 \mu 1\right)$ :

Depletion $\%=\frac{100 \cdot V_{\text {fiber }} \cdot D}{V_{\text {sample }}}$.

\section{Results and discussion}

\subsection{Equilibration time and sample depletion}

The equilibration time was studied under the upper limits and the lower limits of environmentally relevant salinity and $\mathrm{pH}$ (Lutzhoft et al., 2000), i.e., 0 and $500 \mathrm{mM}$ of $\mathrm{NaCl}$, as well as pH 5.0 and $\mathrm{pH} 8.5$, respectively. For studying the effect of salinity, $5 \mathrm{mM}$ of phosphate buffer was adopted to avoid the salinity effect resulted from the high concentration of phosphate. A $30 \mathrm{mM}$ of phosphate buffer was used to provide appropriate buffer capacity for studying the effect of $\mathrm{pH}$. The uptake profiles of BPA to the SPME fiber were shown in Fig. 1 . The calculated $D, k$, and the equilibration time $\left(t_{90 \%}\right.$ and $\left.t_{95 \%}\right)$ according to the fits were shown in Table 1 . The results shown in Table 1 indicate that all these studied factors can influence the equilibration time, and all $t_{90 \%}$ was less than $240 \mathrm{~min}$ except for at $\mathrm{pH}$ 5.0. Fig. 1 clearly shows that under all these studied condi- tions the experimental $C_{\text {fiber }}$ at extraction time of $240 \mathrm{~min}$ was almost the same as that at $360 \mathrm{~min}$, thus it can be conclude that $240 \mathrm{~min}$ is enough for reaching extraction equilibrium and was adopted in the following studies. The equilibration time in our previous study (Cai et al., 2004) was much shorter $(60 \mathrm{~min})$ as analytes were exhaustively extracted (depletion occurred) with a sample volume of $10 \mathrm{ml}$. The effect of DOM on the equilibration time was not studied in this study as previous studies (Lutzhoft et al., 2000; Ohlenbusch et al., 2000) demonstrated that DOM has no significant influence on the equilibration time.

Table 1 also shows the calculated sample depletion that indicates the sample depletion at equilibrium was all less than $3.1 \%$ by using $100 \mathrm{ml}$ of sample.

\subsection{Influence of salinity and $p H$}

The effect salinity and $\mathrm{pH}$ on the availability of BPA was evaluated by measuring the variation of $D$ value resulted from the variation of these environmental conditions. Higher $D$ value indicates the higher availability of BPA. The effect of salinity was studied by using sample solutions ( $50 \mu \mathrm{g}^{-1}$ BPA, pH 7.0) with various concentration of $\mathrm{NaCl}$ in $30 \mathrm{mM}$ and $125 \mathrm{mM}$ phosphate buffer, respectively. As can be seen from Fig. 2(a), the $D$ value increased significantly with salinity in the entire studied range. The $\log D$ value has good linear relationship with the salinity $(S, \mathrm{mM})$, the regression equation and correlation coefficients $\left(r^{2}\right)$ were $\log D=0.0002929 S+3.562\left(r^{2}=0.91\right)$ in $30 \mathrm{mM}$ phosphate buffer, and $\log D=0.0002632 S+3.687$ $\left(r^{2}=0.96\right)$ in $125 \mathrm{mM}$ phosphate buffer, respectively. Fig. 2(a) also indicates that phosphate buffer concentration can affect the $D$ value. For aqueous solution with the same concentration of $\mathrm{NaCl}$, higher concentration of phosphate buffer, i.e., higher salinity, caused higher $D$ value.

The influence of $\mathrm{pH}$ on the distribution of BPA between the fiber and aqueous solutions was investigated by using sample solutions ( $50 \mu \mathrm{g} 1^{-1} \mathrm{BPA}, 125 \mathrm{mM}$ or $30 \mathrm{mM}$ buffer) with various $\mathrm{pH}$ values. The results shown in Fig. 2(b) indicate that the $\log D$ value decreased significantly with the increase of $\mathrm{pH}$ in the studied range of $\mathrm{pH} 5.0-8.5$ under both studied buffer concentrations. Fig. 2(b) also shows the profiles of $\log D$ to $\mathrm{pH}$ after normalizing to the concen-

Table 1

The uptake rate constant $(k)$, distribution coefficient $(D)$, equilibration time and sample depletion from various BPA sample solutions to the nd-SPME fiber

\begin{tabular}{|c|c|c|c|c|c|c|}
\hline \multirow[t]{2}{*}{ Sample matrix } & \multirow[t]{2}{*}{ Varied parameter } & \multirow[t]{2}{*}{$D$} & \multirow[t]{2}{*}{$k\left(\min ^{-1}\right)$} & \multicolumn{2}{|c|}{$\begin{array}{l}\text { Equilibration } \\
\text { time (min) }\end{array}$} & \multirow[t]{2}{*}{$\begin{array}{l}\text { Sample } \\
\text { depletion }(\%)\end{array}$} \\
\hline & & & & $90 \%$ & $95 \%$ & \\
\hline concentration & $500 \mathrm{mM}$ buffer & 7370 & 0.011 & 204 & 265 & 3.1 \\
\hline $5 \mathrm{mM}$ phosphate buffer ( $\mathrm{pH} 7.00$ ) & $0 \mathrm{mM} \mathrm{NaCl}$ & 4952 & 0.012 & 199 & 259 & 2.0 \\
\hline \multirow{2}{*}{$\begin{array}{l}\text { and varied } \mathrm{NaCl} \text { concentration } \\
30 \mathrm{mM} \text { phosphate buffer with varied } \mathrm{pH}\end{array}$} & $500 \mathrm{mM} \mathrm{NaCl}$ & 6490 & 0.014 & 170 & 221 & 2.8 \\
\hline & pH 5.00 & 6396 & 0.0085 & 270 & 352 & 2.8 \\
\hline
\end{tabular}



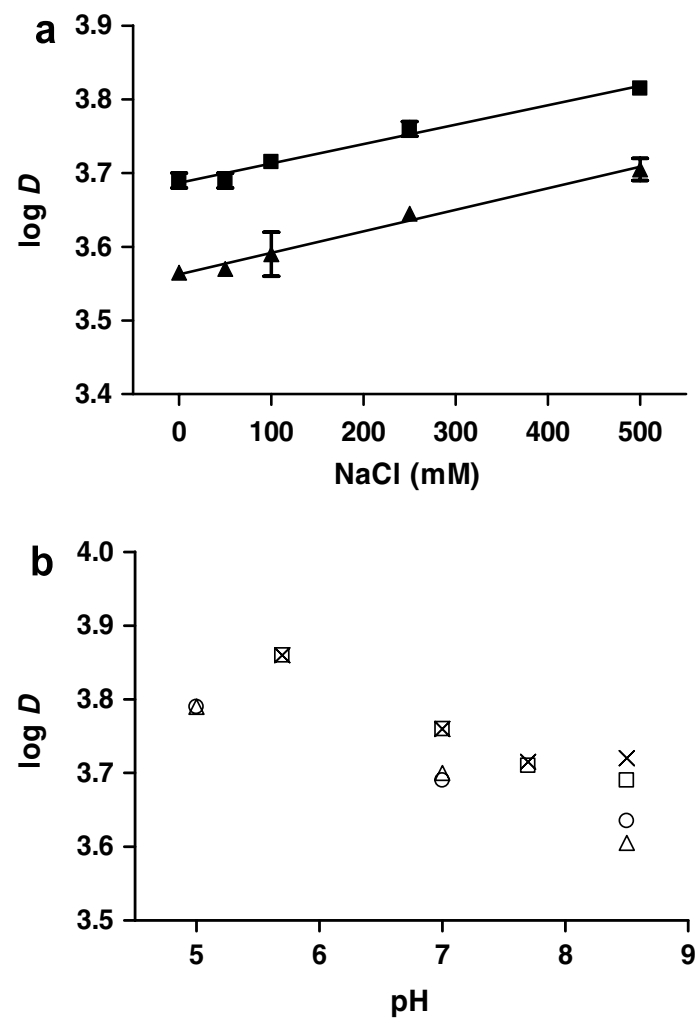

Fig. 2. Influence of salinity and $\mathrm{pH}$ on the partitioning of BPA $\left(50 \mu \mathrm{g}^{-1}\right)$ to the SPME fiber. The vertical lines represent the standard deviations. (a) Effect of salinity: $\mathbf{\square}, 125 \mathrm{mM}$ phosphate buffer (pH 7.0); $\boldsymbol{\Delta}, 30 \mathrm{mM}$ phosphate buffer (pH 7.0). (b) Effect of $\mathrm{pH}$ : $\square, 125 \mathrm{mM}$ phosphate buffer; $\times, 125 \mathrm{mM}$ phosphate buffer, BPA concentration normalized to neutral form; $\triangle, 30 \mathrm{mM}$ phosphate buffer; $\bigcirc, 30 \mathrm{mM}$ phosphate buffer, BPA concentration normalized to neutral form.

tration of the nondissociated form of BPA by adopting $\mathrm{p} K_{\mathrm{a}}=9.60$. As can be seen, the normalization to neutral BPA has no significant change to the profiles. In SPME it is generally assumed that only the neutral species is partitioning into the fiber (Escher et al., 2002) or at least the portioning of the charged species is less than $10 \%$ of the neutral species (Lutzhoft et al., 2000). Therefore, the $D$ value of BPA should be constant as BPA (a weak acid with reported $\mathrm{p} K_{\mathrm{a}}=9.60-10.2$ ) should be present mainly as nondissociated form in the studied $\mathrm{pH}$ range of 5.0-8.5. The reason for the disagreement between the experimental results and the theoretically expected one is not clear yet.

By using nd-SPME (Lutzhoft et al., 2000), the environmentally relevant salinity $(0-500 \mathrm{mM})$ was found to have minor effect on the partitioning of 4-quinolones to fiber, while $\mathrm{pH}$ has strong influence on the partitioning. It was also reported that the addition of $\mathrm{NaCl}$ has no effect on the uptake of carbonyl compounds to polydimethylsiloxane fiber (Bao et al., 1998). However, our experiment results demonstrated that the variation of salinity and $\mathrm{pH}$ could significantly influence the partition of BPA to the fiber, which indicates these environmental factors could influence the availability of BPA. The probable causes for this difference might be that BPA has higher $\mathrm{p} K_{\mathrm{a}}(\geqslant 9.60)$ than the 4-quinolones ( $\mathrm{p} K_{\mathrm{a}}=6.5-6.9$, see Lutzhoft et al.,
2000), thus at around pH 7.0 BPA exists mainly in neutral form while parts of 4-quinolones in ionized form. Therefore, the uptake of BPA to fiber was more sensitive to the influence of salinity due to the salting out effect (Buchholz and Pawliszyn, 1994).

\subsection{Combined effects of humic acids with salinity and $p H$}

Although it was reported that the source of humic acids can be a very important factor for the interaction of humic acids with environmental pollutants, many studies adopted commercial humic acids as a substitute for natural aquatic humic acids to save time and expense for isolation of humic acids from natural waters (Haitzer et al., 1998). Acros humic acid and sodium phosphate buffer were used as models for study the combined effect of DOC and salinity in this present study. As shown in Fig. 3, the freely dissolved fraction of BPA has overall trends of decrease with the increase of Acros humic acid (DOC) concentration at all studied salinity and $\mathrm{pH}$ conditions. As the overall charge of humic acids at $\mathrm{pH} 7.0$ is larger than that at $\mathrm{pH} 6.0$, the binding of BPA to humic acids is relatively strong at $\mathrm{pH} 6.0$ and thus the free fraction of BPA at $\mathrm{pH} 6.0$ is lower than that at $\mathrm{pH}$ 7.0. Keeping the same humic acids concentrations and $\mathrm{pH}$ 7.0, the increase of sodium phosphate buffer from $5 \mathrm{mM}$ to $125 \mathrm{mM}$ resulted in higher freely dissolved fraction of BPA, i.e., the binding of BPA to humic acids was reduced with the increase of salinity, which is in agreement with early studies about nonpolar compounds (Schlautman and Morgan, 1993; Jones and Tiller, 1999; Mezin and Hale, 2004). Fig. 3 also indicates that at high concentration of humic acids (50 $\mathrm{mg}^{-1}$ DOC), the $\mathrm{pH}$ and salinity had minor influence on the binding of BPA to humic acids. In the medium range of humic acids concentration (2.5$25 \mathrm{mg}^{-1}$ DOC), however, the $\mathrm{pH}$ and salinity had significant influence on the binding of BPA to humic acids.

It is interesting that in $5 \mathrm{mM}$ phosphate buffer solutions (both $\mathrm{pH} 6.0$ and $\mathrm{pH} 7.0$ ), the freely dissolved fraction of BPA at $2.5 \mathrm{mg}^{-1}$ DOC was much lower than at any other DOC concentration. This phenomenon was also observed

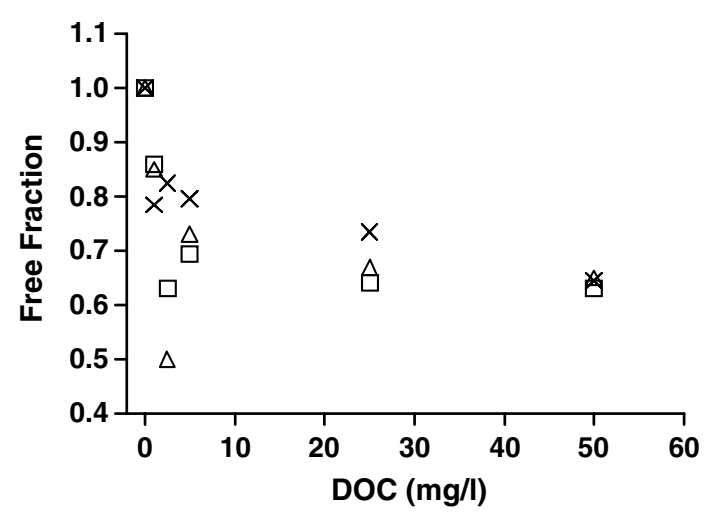

Fig. 3. Effect of Acros humic acid concentration (DOC) on the freely dissolved fraction of BPA $\left(50 \mu \mathrm{g}^{-1}\right)$. $\square, 5 \mathrm{mM}$ phosphate buffer (pH 6.0); $\triangle, 5 \mathrm{mM}$ phosphate buffer ( $\mathrm{pH} 7.0) ; \times, 125 \mathrm{mM}$ phosphate buffer ( $\mathrm{pH} 7.0$ ). 
Table 2

The $\log D_{\mathrm{DOC}}$ of BPA in Acros humic acid solutions with different phosphate concentration and $\mathrm{pH}$ measured by the nd-SPME method

\begin{tabular}{|c|c|c|c|}
\hline \multirow{2}{*}{$\begin{array}{l}\text { DOC concentration } \\
\left(\times 10^{-6}, \mathrm{~kg} \mathrm{l}^{-1}\right)\end{array}$} & \multicolumn{3}{|c|}{$\log D_{\mathrm{DOC}}\left(1 \mathrm{~kg}^{-1}\right.$, mean $\left.\pm s, n=2\right)$} \\
\hline & $\begin{array}{l}5 \mathrm{mM} \text { phosphate buffer, } \\
\text { pH } 6.00\end{array}$ & $\begin{array}{l}5 \mathrm{mM} \text { phosphate buffer, } \\
\text { pH } 7.00\end{array}$ & $\begin{array}{l}125 \mathrm{mM} \text { phosphate buffer, } \\
\text { pH } 7.00\end{array}$ \\
\hline 2.5 & $5.37 \pm 0.02$ & $5.60 \pm 0.02$ & $4.92 \pm 0.11$ \\
\hline 5 & $4.94 \pm 0.01$ & $4.85 \pm 0.18$ & $4.71 \pm 0.07$ \\
\hline 25 & $4.35 \pm 0.06$ & $4.29 \pm 0.10$ & $4.16 \pm 0.06$ \\
\hline 50 & $4.06 \pm 0.06$ & $4.03 \pm 0.08$ & $4.04 \pm 0.05$ \\
\hline
\end{tabular}

in our recent measurement by using equilibrium sampling with 1-octanol supported in the pores of a hollow fiber (results to be published). The reason for this significant deviation from the overall trends is not clear. Probably at this concentration, Acros humic acid was present in a special conformation that has strong binding ability with BPA.

Table 2 shows the $\log D_{\text {DOC }}$ of BPA between the Acros humic acid and the aqueous solutions. The $\log D_{\mathrm{DOC}}$ values of BPA measured in this study were much higher than the reported values (2.93-2.95) (Hollrigl-Rosta et al., 2003). A possible explanation for this is that different DOM was used and it is well known that different DOM exhibited large difference in the capability of binding to organic compounds. On the other hand, the DOC concentration in this present study $\left(1-50 \mathrm{mg}^{-1}\right)$ was much lower than the reported $190 \mathrm{mg}^{-1}$ (Hollrigl-Rosta et al., 2003). From the trends shown in Fig. 3, it can be expected that freely dissolved fraction in $190 \mathrm{mg}^{-1}$ Acros humic acid should be about 0.65 and thus the $\log D_{\text {DOC }}$ should be 3.4 , which is much closer to the reported value of 2.93-2.95.

In conclusion, the $\mathrm{pH}$ and salinity could significantly influence the $D_{\mathrm{DOC}}$ of BPA and thus the bioavailability in most environmentally relevant DOC concentration $\left(<50 \mathrm{mg}^{-1}\right)$.

\section{Acknowledgement}

This work was jointly supported by the National Natural Science Foundation of China (20477052, 20577059) and the National Basic Research Program of China (2003CB415001).

\section{References}

Akkanen, J., Kukkonen, J.V.K., 2001. Effects of water hardness and dissolved organic material on bioavailability of selected organic chemicals. Environ. Toxicol. Chem. 20, 2303-2308.

Arnold, C.G., Ciani, A., Muller, S.R., Amirbahman, A., Schwarzenbach, R.P., 1998. Association of triorganotin compounds with dissolved humic acids. Environ. Sci. Technol. 32, 2976-2983.

Bao, M.-L., Pantani, F., Griffini, O., Burrini, D., Santianni, D., Barbieri, K., 1998. Determination of carbonyl compounds in water by derivatization-solid-phase microextraction and gas chromatographic analysis. J. Chromatogr. A 809, 75-87.

Basheer, C., Parthiban, A., Jayaraman, A., Lee, H.K., Valiyaveettil, S., 2005. Determination of alkylphenols and bisphenol-A-A comparative investigation of functional polymer-coated membrane microex- traction and solid-phase microextraction techniques. J. Chromatogr. A 1087, 274-282.

Braun, P., Moeder, M., Schrader, S., Popp, P., Kuschk, R., Engewald, W., 2003. Trace analysis of technical nonylphenol, bisphenol A and 17 alpha-ethinylestradiol in wastewater using solid-phase microextraction and gas chromatography-mass spectrometry. J. Chromatogr. A 988, $41-51$.

Brunk, B.K., Jirka, G.H., Lion, L.W., 1997. Effects of salinity changes and the formation of dissolved organic matter coatings on the sorption of phenanthrene: implications for pollutant trapping in estuaries. Environ. Sci. Technol. 32, 119-125.

Buchholz, K.D., Pawliszyn, J., 1994. Optimization of solid-phase microextraction conditions for determinations of phenols. Anal. Chem. 66, 160-167.

Cai, Y.Q., Jiang, G.B., Liu, J.F., Liang, X., Yao, Z.W., Liu, J.M., Liu, J.Y., Zhou, Q.X., 2004. Solid-phase microextraction coupled with high performance liquid chromatography-fluorimetric detection for the determination of bisphenol A, 4-n-nonylphenol, and 4-tert-octylphenol in environmental water samples. Anal. Lett. 37, 739-754.

Carter, C., Suffet, I., 1982. Binding of DDT to dissolved humic materials. Environ. Sci. Technol. 16, 735-740.

Chang, C.M., Chou, C.C., Lee, M.R., 2005. Determining leaching of bisphenol A from plastic containers by solid-phase microextraction and gas chromatography-mass spectrometry. Anal. Chim. Acta 539, 41-47.

Chin, Y.-P., Aiken, G.R., Danielsen, K.M., 1997. Binding of pyrene to aquatic and commercial humic substances: The role of molecular weight and aromaticity. Environ. Sci. Technol. 31, 1630-1635.

Day, K.E., 1991. Effects of dissolved organic carbon on accumulation and acute toxicity of fenvalerate, deltamethrin and cyhalothrin to Daphnia magna (Strauss). Environ. Toxicol. Chem. 10, 91-101.

Escher, B.I., Schwarzenbach, R.P., 1996. Partitioning of substituted phenols in liposome-water, biomembrane-water, and octanol-water systems. Environ. Sci. Technol. 30, 260-270.

Escher, B.I., Berg, M., Muhlemann, J., Schwarz, M.A.A., Hermens, J.L.M., Vaes, W.H.J., Schwarzenbach, R.P., 2002. Determination of liposome/water partition coefficients of organic acids and bases by solid-phase microextraction. Analyst 127, 42-48.

Gauthier, T.D., Shane, E.C., Guerin, W.F., Seitz, W.R., Grant, C.L., 1986. Fluorescence quenching method for determining equilibrium constants for polycyclic aromatic hydrocarbons binding to dissolved humic materials. Environ. Sci. Technol. 20, 1162-1166.

Haitzer, M., Hoss, S., Traunspurger, W., Steinberg, C., 1998. Effects of dissolved organic matter (DOM) on the bioconcentration of organic chemicals in aquatic organisms-A review. Chemosphere 37, 13351362.

Hollrigl-Rosta, A., Vinken, R., Lenz, M., Schaffer, A., 2003. Sorption and dialysis experiments to assess the binding of phenolic xenobiotics to dissolved organic matter in soil. Environ. Toxicol. Chem. 22, 746-752.

Jones, K.D., Tiller, C.L., 1999. Effect of solution chemistry on the extent of binding of phenanthrene by a soil humic acid: a comparison of dissolved and clay bound humic. Environ. Sci. Technol. 33, 580-587.

Jota, M.A.T., Hassett, J.P., 1991. Effects of environmental variables on binding of a PCB congener by dissolved humic substances. Environ. Toxicol. Chem. 10, 483-491. 
Kukkonen, J., Oikari, A., 1987. Effects of aquatic humus on accumulation and acute toxicity of some organic pollutants. Sci. Total Environ. 62, $399-402$.

Liu, J.F., Jönsson, J.Å., Mayer, P., 2005. Equilibrium sampling through membranes of freely dissolved chlorophenols in water samples with hollow fiber supported liquid membrane. Anal. Chem. 77, 4800-4809.

Lutzhoft, H.-C.H., Vaes, W.H.J., Freidig, A.P., Halling-Sorensen, B., Hermens, J.L.M., 2000. Influence of $\mathrm{pH}$ and other modifying factors on the distribution behavior of 4-quinolones to solid phases and humic acids studied by "negligible-depletion" SPME-HPLC. Environ. Sci. Technol. 34, 4989-4994.

Mackay, D., Paterson, S., 1991. Evaluating the multimedia fate of organic chemicals: a level III fugacity model. Environ. Sci. Technol. 25, 427436.

Mayer, P., Tolls, J., Hermens, J.L.M., Mackay, D., 2003. Equilibrium sampling devices. Environ. Sci. Technol. 37, 185A-191A.

Mezin, L.C., Hale, R.C., 2004. Combined effects of humic acids and salinity on solid-phase microextraction of DDT and chlorpyrifos, an estimator of their bioavailability. Environ. Toxicol. Chem. 23, 576582.
Ohlenbusch, G., Kumke, M.U., Frimmel, F.H., 2000. Sorption of phenols to dissolved organic matter investigated by solid phase microextraction. Sci. Total Environ. 253, 63-74.

Paolis, F.D., Kukkonen, J., 1997. Binding of organic pollutants to humic and fulvic acids: influence of the $\mathrm{pH}$ and the structure of humic material. Chemosphere 34, 1693-1704.

Salafranca, J., Batlle, R., Nerin, C., 1999. Use of solid-phase microextraction for the analysis of bisphenol A and bisphenol A diglycidyl ether in food simulants. J. Chromatogr. A 864, 137-144.

Schlautman, M.A., Morgan, J.J., 1993. Effects of aqueous chemistry on the binding of polycyclic aromatic hydrocarbons by dissolved humic materials. Environ. Sci. Technol. 27, 961-969.

Staples, C.A., Dorn, P.B., Klecka, G.M., Oblock, S.T., Harris, L.R., 1998. A review of the environmental fate, effects, and exposures of bisphenol A. Chemosphere 36, 2149-2173.

Suffet, I.H., Javfert, C.T., Kukkonen, J., Servos, M.R., Spacie, A., Williams, L.L., Noblet, J.A., 1994. Synopsis of Discussion Session: Influences of Particulate and Dissolved Material on the Bioavailability of Organic Compounds. CRC Press (Lewis Publishers), Boca Raton, FL, USA, pp. 93-107. 